\title{
Thyroid Hormones and Active Calcium Transport of Inside-Out Red Cell Membrane Vesicles
}

\author{
Alessandro Rubinacci, Paola Divieti, Stefano Lodigiani, \\ Alessandro De Ponti, ${ }^{*}$ and Michele Samaja* \\ Sezione Fisiopatologia dell'Osso e del Metabolismo Minerale, ${ }^{*}$ Dipartimento di Scienze e Tecnologie \\ Biomediche, Istituto Scientifico San Raffaele, Università di Milano, via Olgettina 60, \\ 20132 Milano, Italy
}

Received June 2, 1992

\begin{abstract}
Thyroid hormones may influence the active transport of $\mathrm{Ca}^{2+}$ across the cell membrane. To test the physiologic relevance of this mechanism, we used inside-out human red cell membrane vesicles as a model of the cell membrane $\mathrm{Ca}^{2+}$ pump. We monitored by spectrophotometric methods the kinetics of the uptake of $\mathrm{Ca}^{2+}$ in the presence of $10^{-5}-10^{-10}$ $\mathrm{m}$ thyroid hormones or their analogues. Vesicles freed of calmodulin and protein inhibitor(s) of the $\mathrm{Ca}^{2+}$ pump were also obtained. The results are as follows: (1) Thyroxine inhibits the active $\mathrm{Ca}^{2+}$ uptake; (2) this effect antagonizes that of soluble calmodulin; and (3) triiodothyronine and other analogues of the thyroid hormones are less active than thyroxine. We conclude that the thyroid hormones may influence cell $\mathrm{Ca}^{2+}$ homeostasis by direct action on the $\mathrm{Ca}^{2+}$ pump. 1992 Academic Press, Inc.
\end{abstract}

The mechanism underlying the regulation of the cell activities by thyroid hormones $^{1}$ involves the nuclear components of the cell (1). In addition to this mechanism, it was found that TH affect the activity of $\mathrm{Ca}^{2+}-$ ATPase or the response of $\mathrm{Ca}^{2+}$-ATPase to CaM $(2,3)$. It was thus proposed that the action of TH is also exerted through modulation of the homeostasis of $\mathrm{Ca}^{2+}$. However, $\mathrm{Ca}^{2+}$-ATPase is only one of the components of the $\mathrm{Ca}^{2+}$ pump, which is influenced by several interacting factors including the microenvironment of the enzyme, CaM, the protein inhibitors of the $\mathrm{Ca}^{2+}$ pump and other intracellular factors (4). Therefore, the physiologic relevance of that observation is questionable.

We investigated the effect of $\mathrm{TH}$ on the active $\mathrm{Ca}^{2+}$ transport by IORCMV to test whether the observed stimulation on $\mathrm{Ca}^{2+}$-ATPase persists in a physiologic model. The IORCMV (5) are particularly suitable for this purpose because the intracellular structures are ruled out. The reversed orientation of the membrane

1 Abbreviations used: CaM, calmodulin; IORCMV, inside-out red cell membrane vesicles; RBC, red blood cell; TH, thyroid hormones; $\mathrm{T}_{4}, 3,3^{\prime}, 5,5^{\prime}$-L-thyroxine; $\mathrm{T}_{3}, 3,3^{\prime}, 5$-triiodo-L-thyronine; $\mathrm{DT}_{3}$, 3,3',5-triiodo-D-thyronine; $\mathrm{rT}_{3}, 3,3^{\prime}, 5^{\prime}$-triiodo-L-thyronine; Triac, 3,3',5-triiodothyroacetic acid. 
exposes its inner face to the experimental conditions eliminating interferences by cell surface receptors and internalization processes. In addition, membrane-bound $\mathrm{CaM}$ and protein inhibitor(s) of the $\mathrm{Ca}^{2+}$ pump were selectively removed to identify the role of these factors. The specificity of the effect of TH was assessed using structural analogues.

\section{MATERIALS AND METHODS}

Reagents. All reagents were provided from Sigma Chemicals (St. Louis, MO) and were analytical grade. Arsenazo III was freed of $\mathrm{Ca}^{2+}$ ions by passage through a Chelex-100 resin (Bio-Rad Laboratories).

Inside-out red cell membrane vesicles. Fresh heparinized blood samples were obtained from euthyroid and healthy female volunteers (age $25 \pm 4$ years, means $\pm \mathrm{SE}$, range 21-35 years) as part of a study into the pathogenesis of disturbancies of mineral metabolism which frequently affect the female population. The IORCMV were prepared as previously described (6) washing the RBC with 154 $\mathrm{mm} \mathrm{NaCl}$, hemolyzing them with $5 \mathrm{~mm}$ phosphate buffer at $\mathrm{pH} 8$, and repeatedly washing the ghosts with the same buffer. To obtain vesicles where endogenous $\mathrm{CaM}$ and the inhibitors of the $\mathrm{Ca}^{2+}$ pump are quantitatively removed, part of the ghosts were washed three times with $5 \mathrm{~mm}$ phosphate at $\mathrm{pH} 8$ and $1 \mathrm{~mm}$ EDTA (7). EDTA was removed by further washing IORCMVs in EDTA-free buffer three times. Ghosts were finally incubated overnight at $4^{\circ} \mathrm{C}$ in a $0.5 \mathrm{~mm}$ phosphate at $\mathrm{pH} 8$.

Vesiculation was initiated by passage through a 27 gauge $\times 3 / 4$ in. needle, and the percentage of inside-out vesicles was estimated by the acetylcholinesterase accessibility assay (5). The total protein concentration of the IORCMV suspension was measured with the bicinchoninic acid assay (Pierce Chemical).

The active calcium uptake. The calcium uptake by IORCMV was monitored at $37^{\circ} \mathrm{C}$ by the absorbance change recorded by a dual-wavelength spectrophotometer DW2A (American Instrument Co., Silver Spring, MD) operating at 675-685 nm to offset the interferences due to the turbidity of the suspension, $\mathrm{Mg}^{2+}$, and $\mathrm{pH}$. The active $\mathrm{Ca}^{2+}$ uptake was initiated adding $0.5 \mathrm{~nm}$ ATP to the incubation medium containing the vesicles (3-4 $\mathrm{mg} / \mathrm{ml}$ total protein), $0.02 \mathrm{~mm} \mathrm{CaCl}, 1 \mathrm{mM} \mathrm{MgCl}_{2}$, $0.1 \mathrm{M} \mathrm{KCl}, 5 \mathrm{~mm}$ sodium azide, and $0.1 \mathrm{~mm}$ Arsenazo III. The maximally activated calcium uptake was obtained adding $250 \mathrm{IU}$ CaM to the mixture. Data are expressed as micromoles of $\mathrm{Ca}^{2+}$ uptaken per minute per milligram of protein and are corrected for the actual percentage of inside-out vesicles.

Thyroid hormones. TH (Sigma) were dissolved in $0.5 \mathrm{~mm}$ phosphate, $\mathrm{pH} 8$, at $25^{\circ} \mathrm{C}$, titrated to $\mathrm{pH} 7.5$ with $\mathrm{NaOH}$, and were kept at $0^{\circ} \mathrm{C}$ for no longer than 4 h. The kinetics of $\mathrm{Ca}^{2+}$ uptake were measured using various amounts of $\mathrm{TH}$ in the same volume $(10 \mu \mathrm{l})$. TH were added to the cuvette during the linear portion of the active $\mathrm{Ca}^{2+}$ uptake.

Statistics. All data are expressed as means $\pm \mathrm{SE}$ and compared using the Student's $t$ test for unpaired observations. When the inhibition by TH and their analogues was considered, the paired Student's $t$ test was used. 
TABLE 1

Effect of $\mathrm{T}_{4}$ on the $\mathrm{Ca}^{2+}$ Uptake ( $\mu \mathrm{mol} \mathrm{Ca} \mathrm{Ca}^{2+} / \mathrm{min} / \mathrm{mg}$ protein) by Untreated and EDTA-Treated IORCMV

\begin{tabular}{|c|c|c|c|c|c|}
\hline \multirow[b]{2}{*}{ IORCMV } & \multirow{2}{*}{$\begin{array}{c}\mathrm{CaM} 250 \\
\mathrm{IU} / \mathrm{ml}\end{array}$} & \multirow[b]{2}{*}{$n$} & \multicolumn{2}{|c|}{$10^{-5} \mathrm{M} \mathrm{T}_{4}$} & \multirow[b]{2}{*}{$P^{*}$} \\
\hline & & & Before & After & \\
\hline \multirow{2}{*}{ Untreated } & No & 6 & $1.6 \pm 0.3$ & $1.5 \pm 0.3$ & NS \\
\hline & Yes & 15 & $2.3 \pm 0.1$ & $1.8 \pm 0.1$ & $<0.0005$ \\
\hline \multirow{2}{*}{ EDTA-treated $^{a}$} & No & 8 & $0.9 \pm 0.2$ & $0.9 \pm 0.2$ & NS \\
\hline & Yes & 12 & $2.4 \pm 0.3$ & $2.0 \pm 0.3$ & $<0.0005$ \\
\hline
\end{tabular}

Note. Data are means \pm SE.

${ }^{a}$ Endogenous CaM and inhibitors removed.

* The significance level refers to the difference between the $\mathrm{Ca}^{2+}$ uptake before and after addition of $T_{4}$ (Student's $t$ test for paired data).

\section{RESULTS}

The IORCMV preparations tested in this study were stable and linear during the maximally activated $\mathrm{Ca}^{2+}$ uptake for at least $5 \mathrm{~min}$ (not shown). No $\mathrm{Ca}^{2+}$ chelation by $\mathrm{TH}$ was evident from lack of absorbance changes on addition of $\mathrm{TH}$ to the medium.

In the absence of soluble CaM, the addition of $10^{-5} \mathrm{M} \mathrm{T}_{4}$ did not affect the active $\mathrm{Ca}^{2+}$ uptake of IORCMV (Table 1). In contrast, $\mathrm{T}_{4}$ inhibited the active $\mathrm{Ca}^{2+}$ uptake of untreated IORCMV by $21 \pm 2 \%$ in the presence of excess soluble CaM. When the IORCMV were treated with EDTA to remove membrane-bound $\mathrm{CaM}$ and the inhibitor(s) of the $\mathrm{Ca}^{2+}$ pump, the uptake of $\mathrm{Ca}^{2+}$ decreased, but the maximally activated uptake was independent of the treatment, as expected (6). Under these conditions, the inhibition by $\mathrm{T}_{4}$ was $17 \pm 3 \%$ in the presence of soluble CaM.

The magnitude of the inhibition exerted by $\mathrm{T}_{4}$ on the maximally activated $\mathrm{Ca}^{2+}$ uptake was dose dependent in the $10^{-10}-10^{-5} \mathrm{M} \mathrm{T}_{4}$ range (Fig. 1). The inhibition was unaffected by pretreatment of the ghosts with EDTA.

The effect of triiodothyronine and other analogues $\left(\mathrm{rT}_{3}, \mathrm{DT}_{3}\right.$, and Triac) on the maximally activated $\mathrm{Ca}^{2+}$ uptake was tested at $10^{-5} \mathrm{M}$ TH (Table 2).

\section{DISCUSSION}

In the IORCMV model, $\mathrm{T}_{4}$ inhibited the $\mathrm{Ca}^{2+}$ pump in the presence of excess soluble $\mathrm{CaM}$ in the medium. No effect of $\mathrm{T}_{4}$ was observed in the absence of soluble CaM. This feature was not dependent on the presence of membranebound $\mathrm{CaM}$ and of the protein inhibitor(s) of the $\mathrm{Ca}^{2+}$ pump. The effect of $\mathrm{T}_{4}$ was dose dependent without apparent saturation of the response in the $10^{-5}$ $10^{-10} \mathrm{M} \mathrm{T}_{4}$ range. The analogues of $\mathrm{TH}$ inhibited the $\mathrm{Ca}^{2+}$ uptake but to a lower extent than $\mathrm{T}_{4}$.

Due to the peculiarities of the IORCMV model, the effect of $T_{4}$ on the maximally activated $\mathrm{Ca}^{2+}$ uptake appears associated to factors present on the cell membrane. Cell surface receptors and carriers are not involved, but the presence 


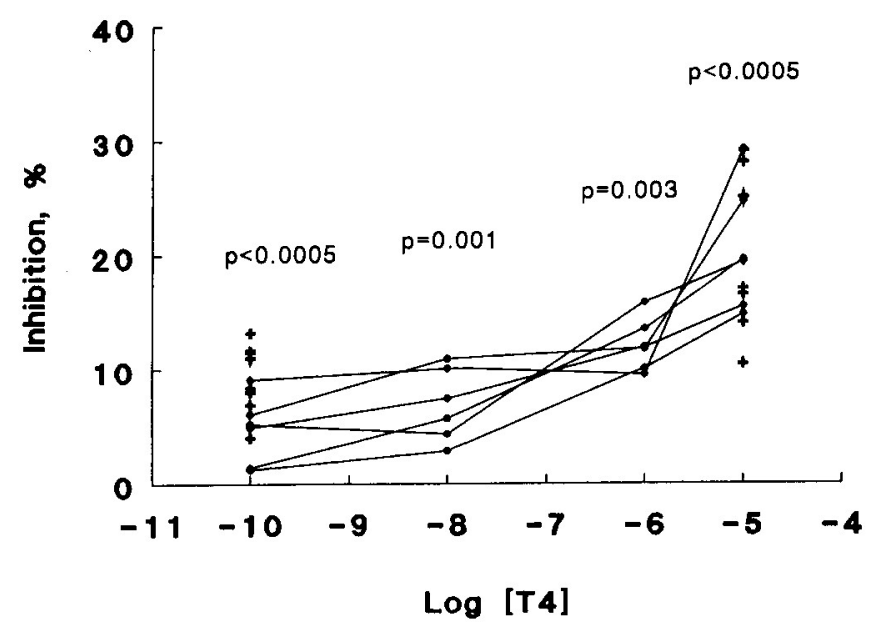

Fig. 1. Inhibition of the maximally activated $\mathrm{Ca}^{2+}$ uptake at varying concentrations of $\mathrm{T}_{4}$ in untreated IORCMV $\left(20 \mu \mathrm{M} \mathrm{Ca}{ }^{2+}, 500 \mu \mathrm{M}\right.$ ATP, and $\left.250 \mathrm{IU} / \mathrm{ml} \mathrm{CaM}\right)$. All data obtained under these conditions are shown and were used for the Student's $t$ test for paired observations. Some samples, analyzed at different concentrations of $\mathrm{T}_{4}$, are indicated by solid lines.

of soluble CaM is critical. Membrane-bound $\mathrm{CaM}$ and protein inhibitor(s) are not relevant.

Previous work on the effect of $\mathrm{TH}$ on the active $\mathrm{Ca}^{2+}$ transport in the $\mathrm{RBC}$ membrane concerned the hydrolytic activity of $\mathrm{Ca}^{2+}-\mathrm{ATPase}(2,3,8)$. Incubation $\left(60-120 \mathrm{~min}\right.$ at $\left.37^{\circ} \mathrm{C}\right)$ of RBC ghosts with $\mathrm{T}_{4}$ or $\mathrm{T}_{3}$ stimulated such activity (2), likely through interaction with $\mathrm{CaM}(8)$. These results are in contrast with the loss of any effect by $\mathrm{T}_{4}$ following maximal activation of $\mathrm{Ca}^{2+}-\mathrm{ATPase}$ by $\mathrm{CaM}(3)$. These authors suggest an indirect effect of $\mathrm{T}_{4}$ on $\mathrm{RBC}$ membrane stability, lipid microdomain or CaM binding.

The inhibition of the $\mathrm{Ca}^{2+}$ pump activity by $\mathrm{T}_{4}$ reported here is in apparent

TABLE 2

Effect of $10^{-5} \mathrm{M} \mathrm{T}_{4}$ and Analogues on the Active CaM-Activated Transport of $\mathrm{Ca}^{2+}$ in the Insideout Red Cell Membrane Vesicles

\begin{tabular}{|c|c|c|c|c|c|c|}
\hline & $n$ & Basal & $\begin{array}{c}\text { CaM- } \\
\text { activated }\end{array}$ & $\begin{array}{c}\text { After addition } \\
\text { of } \mathrm{TH} \\
\text { analogue }\end{array}$ & $\begin{array}{c}\% \\
\text { Inhibition }\end{array}$ & $P$ \\
\hline $\mathrm{T}_{4}$ & 15 & $1.0 \pm 0.1$ & $2.3 \pm 0.1$ & $1.8 \pm 0.1$ & $21 \pm 2$ & $<0.0005$ \\
\hline $\mathrm{T}_{3}$ & 10 & $1.3 \pm 0.2$ & $3.0 \pm 0.4$ & $2.8 \pm 0.4$ & $8 \pm 2$ & 0.002 \\
\hline $\mathrm{rT}_{3}$ & 6 & $1.6 \pm 0.3$ & $3.3 \pm 0.4$ & $3.1 \pm 0.4$ & $7 \pm 2$ & 0.048 \\
\hline $\mathrm{DT}_{3}$ & 7 & $1.4 \pm 0.2$ & $3.0 \pm 0.3$ & $2.6 \pm 0.3$ & $12 \pm 2$ & 0.008 \\
\hline Triac & 8 & $1.4 \pm 0.2$ & $2.9 \pm 0.2$ & $2.8 \pm 0.2$ & $3 \pm 3$ & NS \\
\hline
\end{tabular}

Note. $\mathrm{T}_{4}=3,3^{\prime}, 5,5^{\prime}$-L-thyroxine; $\mathrm{T}_{3}=3,5,3^{\prime}$-triiodo-L-thyronine, $\mathrm{rT}_{3}, 3,3^{\prime}, 5^{\prime}$-triiodo-L-thyronine; $\mathrm{DT}_{3}, 3,3^{\prime}, 5$-triiodo-D-thyronine; Triac, 3,3',5-triiodothyroacetic acid. $\mathrm{Ca}^{2+}$ uptake expressed as $\mu$ mol $\mathrm{Ca}^{2+} / \mathrm{min} / \mathrm{mg}$ protein. 
contrast with the above reports. If differences in the lipid composition of the plasma membrane and sex/age of the donors are ruled out (9), the importance of the experimental model employed becomes critical. We believe that the IORCMV model is better suitable than purified $\mathrm{Ca}^{2+}-\mathrm{ATPase}$ to examine the reactivity of the $\mathrm{Ca}^{2+}$ pump toward perturbators. In fact, the IORCMV model integrates several components of the $\mathrm{Ca}^{2+}$ pump system, i.e., the hydrolytic and transport functions, the lipid microdomain of the enzyme, endogenous CaM, and the inhibitors of $\mathrm{Ca}^{2+}-\mathrm{ATPase}$. In contrast, the $\mathrm{Ca}^{2+}-\mathrm{ATPase}$ model is based on the enzyme hydrolytic activity, which is one only component of the $\mathrm{Ca}^{2+}$ pump assembly. It was already suggested that $\mathrm{Ca}^{2+}-\mathrm{ATPase}$ and the $\mathrm{Ca}^{2+}$ pump functions could be dissociated in the presence of TH (10), and that the response of the enzymatic system to the action of $\mathrm{T}_{4}$ could be conditioned by the lipid microdomain of the enzyme $(9,10)$.

The dependency on the concentration was tested in the $10^{-10}-10^{-5} \mathrm{M} \mathrm{T}_{4}$ range. Although the physiologic relevance of the latter concentration is questionable, it is worth note that the carrier-mediated membrane transport system can concentrate $\mathrm{TH}$ into the cell up to 74 times the concentration found in plasma when rat liver cells are incubated with physiologic concentrations of $T_{3}$ for $60 \mathrm{~s} \mathrm{(11).} \mathrm{Molecular}$ alterations of $\mathrm{T}_{4}$ reduced the inhibition of the $\mathrm{Ca}^{2+}$ pump indicating that this effect is highly specific for $\mathrm{T}_{4}$.

In conclusion, this study indicates that $T_{4}$ exerts an inhibition on the RBC membrane $\mathrm{Ca}^{2+}$ pump similar to the action of $\mathrm{TH}$ on oxidative phosphorylation in liver mitochondria which is not mediated by interaction with the nucleus (12). Interaction of soluble $\mathrm{CaM}$ to $\mathrm{Ca}^{2+}-\mathrm{ATPase}$ is critical in this mechanism. An increasing amount of evidence indicates that the characteristics of RBC membrane $\mathrm{Ca}^{2+}$-ATPase are similar to those of other systems such as osteoblasts (13), adipocytes (14), and renal tubular cells (15). Thus, the mechanism described here may be extended to other cell types as well, as already suggested (10).

\section{ACKNOWLEDGMENTS}

We thank Professor Luigi Tessari for the critical revision of the manuscript. This study was supported by a grant from the Consiglio Nazionale delle Ricerche, Italy (No. 92-3-181).

\section{REFERENCES}

1. Utiger RD. The thyroid: Physiology, hyperthyroidism, hypothyroidism, and the painful thyroid. In Endocrinology and Metabolism (Felig P, Baxter JD, Broadus AE, Frohman LA, Eds.). New York: McGraw-Hill, 1987, pp 389-484.

2. Davis PJ, Blas SD. In vitro stimulation of human red blood cell Ca ATPase by thyroid hormone. Biochem Biophys Res Commun 99:1073-1080, 1981.

3. Costante G, Sand G, Connart D, Glinoer D. In vitro effects of thyroid hormones on red blood cell Ca-dependent ATPase activity. J Endocrinol Invest 9:15-20, 1986.

4. Carafoli E. Intracellular calcium homeostasis. Annu Rev Biochem 56:395-433, 1987.

5. Steck TL, Kant JA. Preparation of impermeable ghosts and inside-out vesicles from human erythrocyte membranes. Methods Enzymol 31:172-180, 1974.

6. Samaja M, Rubinacci A, De Ponti A, Portinaro N. The effect of in vitro and in vivo cellular aging on the active calcium transport in human inside-out red cell membrane vesicles. Biochem Biophys Res Commun 159:432-438, 1989. 
7. Au KS, Lee KS. A protein modulator of erythrocyte membrane $(\mathrm{Ca}+\mathrm{Mg})$-ATPase inhibitor protein. Biochim Biophys Acta 784:108-115, 1984.

8. Davis FB, Cody V, Davis PJ, Borzynski LJ, Blas SD. Stimulation by thyroid hormone analogues of red blood cell Ca-ATPase activity in vitro. J Biol Chem 258:12373-12378, 1983.

9. Galo MG, Unates LE, Farias RN. Effect of membrane fatty acid composition on the action of thyroid hormones on $(\mathrm{Ca}+\mathrm{Mg})$-adenosine triphosphatase from rat erythrocyte. J Biol Chem 256:7113-7114, 1981.

10. Davis PJ, Davis FB, Lawrence WD. Thyroid hormone regulation of membrane Ca-ATPase Activity. Endocr Res 15:651-682, 1989.

11. Rao GS, Rao ML, Thilmann A, Quednau HD. Study of fluxes at low concentrations of L-triiodothyronine with rat liver cells and their plasma-membrane vesicles. Biochem $J$ 198:457-466, 1981.

12. Hafner RP. Thyroid hormone uptake into the cell and its subsequent localisation to the mitochondria. FEBS Lett 224:251-256, 1987.

13. Shen V, Hruska K., Avioli LV. Characterization of a $\left(\mathrm{Ca}^{++}+\mathrm{Mg}^{++}\right)$-ATPase system in the osteoblast plasma membrane. Bone 9:325-329, 1988.

14. Pershadsingh HA, McDonald JM. A high affinity calcium-stimulated magnesium-dependent adenosine triphosphatase in rat adipocyte plasma membrane. J Biol Chem 255:4087-4093, 1980.

15. Borke JL, Minami J, Verma A, Penniston JT, Kumar R. Monoclonal antibodies to human erythrocyte membrane $\mathrm{Ca}-\mathrm{Mg}$ adenosine triphosphatase pump recognize an epitope in the basolateral membrane of human kidney distal tubule cells. J Clin Invest 80:1225-1231, 1987. 